\title{
Swimming against the tide: Comparative lessons from government efforts to prohibit private supplementary tutoring delivered by regular teachers
}

\author{
MARK BRAY $Y^{1,2 *}$ \\ ${ }^{1}$ Centre for International Research in Supplementary Tutoring (CIRIST), Faculty of Education, East \\ China Normal University, Shanghai, China \\ ${ }^{2}$ Comparative Education Research Centre, The University of Hong Kong, Pok Fu Lam, Hong Kong
}

\section{ORIGINAL RESEARCH PAPER}

\section{ABSTRACT}

Private supplementary tutoring, widely known as shadow education, has become a global phenomenon. It has a range of providers, including commercial companies, university students desiring extra pocket money, and regular school teachers who provide tutoring as a sideline activity. This paper focuses on the last category.

Governments are commonly ambivalent about the existence of shadow education, and may especially disapprove of regular teachers providing private supplementary tutoring in part because they fear that the teachers will neglect their main duties. With such matters in mind, some governments have attempted to prohibit teachers from providing private tutoring. However, such prohibitions are difficult to implement. This paper analyses situations in Korea, Mauritius, Kenya and England in order to derive comparative lessons from experience. It demonstrates the importance of wider contextual factors including alignment of macro-level aspirations with the micro-level perspectives of families finding themselves in increasingly competitive environments.

\section{KEYWORDS}

private supplementary tutoring, shadow education, teachers, prohibitions, England, Kenya, Korea, Mauritius

\footnotetext{
*Corresponding author. E-mail: mbray@hku.hk
} 


\section{INTRODUCTION}

The literature on private supplementary tutoring - widely known as shadow education because much of its content mimics that provided in mainstream schools - identifies three main categories of suppliers (e.g. Aurini, Davies, \& Dierkes, 2013; Bray, 2009; Zhang \& Yamato, 2018). One category embraces companies of different sizes that offer tutoring on a local, national, or international basis. Another category is of university students and others who provide tutoring informally to earn extra pocket money. The third, which is the focus of this paper, covers teachers who are employed full-time in regular schools and who offer private tutoring as a side activity to earn additional income.

Governments are commonly uneasy about the provision of private supplementary tutoring by serving teachers. They are mindful that teachers with demanding supplementary activities might put less effort into their main employment, and that in this respect the shadow education will detract from mainstream schooling. Authorities are especially concerned about situations in which teachers tutor their existing students, recognising the danger that teachers will grant favours to those students in their regular classes and discriminate against other students, thereby exerting pressures in ways that are arguably corrupt (see e.g. Bray, 2003; Dawson, 2009; Jayachandran, 2014). However, once the practice has entered the general culture it is very difficult to remove.

The phenomenon of teachers providing private supplementary lessons may be found in countries as diverse as Cambodia, Egypt, France, and Zimbabwe (Bray, Kobakhidze, Zhang, \& Liu, 2018; Graveleau, 2020; Ille \& Peacey, 2019; Makwerere \& Dube, 2019). In some of these countries the phenomenon has a long history and flourishes despite government policies of discouragement and even prohibition, while in others it is more recent and growing in a laissez faire environment. Elsewhere the private supplementary tutoring provided by regular teachers has declined, in part because of government policies but also because the commercial sector has become more vigorous and to a large extent has displaced the supplementary roles of teachers (see e.g. Entrich, 2018; Yung \& Bray, 2017).

This paper reviews forces in a range of countries, framing discussion with remarks about expanded schooling, changing roles of the state, and household demand. It elaborates on patterns in Korea, Mauritius, Kenya and England to illustrate the themes through case studies. ${ }^{1}$ The fact that these countries have very diverse histories and cultures underlines the significance of the commonalities. The paper shows that governments can reduce and perhaps even eliminate this practice with very strong efforts, but they have to swim strongly against the tide of desires by many teachers to provide private supplementary tutoring coupled in many cases by desires by parents for those teachers to provide the additional service. Economic, cultural and other contextual factors have much significance, as well as dynamics within the education sector itself.

\section{EXPANDED SCHOOLING, CHANGING ROLES OF THE STATE, AND HOUSEHOLD DEMAND}

Over the decades since the 19th century, and gathering speed during the second half of the 20th century, schooling has expanded throughout the world to become a universal phenomenon

${ }^{1}$ Korea in this paper refers to the Republic of Korea, also commonly called South Korea. 
(Baker, 2014; Benavot \& Resnick, 2006). Commencing with the 1948 Universal Declaration of Human Rights, at a global level the agenda has been pushed by the United Nations and its specialist bodies. These bodies have particularly advocated universalisation of primary and lower-secondary education, and have also advocated expanded early-childhood, upper-secondary and higher education (see e.g. Inter-Agency Commission, 1990; UNESCO, 2000, 2015). Related recommendations have been made by the Organisation for Economic Co-operation and Development (e.g. OECD, 2001). Parts of this agenda have been based over the decades on assertions that, for example, education "is critical for economic growth and poverty reduction" (World Bank, 1995: 1). A more recent assertion by the United Nations Deputy Secretary General (Mohammed, 2020) is even more sweeping. She declared that:

Education certainly has the power to shape our world. Education is protecting men and women from exploitation in the labour market. It is empowering women and certainly gives them the opportunity to make their choices. Education can help change behaviours and mindsets, and thereby we see the fight against climate change and unsustainable practices taking hold. Education also promotes the mutual respect, understanding and tolerance of each and every one of us in our human family....

In other words, education is commonly described by advocates in these agencies in glowing terms and even as a panacea that much deserves further investment.

At the other end of the scale from the United Nations and its agencies are ordinary households. Generations of families have viewed education as a core instrument to retain their places in higher social strata or to access those strata. Across the globe, many parents, especially in the middle classes, have made huge financial and other sacrifices in family life to prioritise education for their children in both quantity and quality with a view towards successful careers and expanded life opportunities.

Alongside the global organisations and individual households, and between them in the scale of their remit, are governments. With their own ideologies both to lead and to respond to popular demand, governments have provided increasing volumes of formal education at all levels. As the 20th century progressed, schooling was increasingly viewed as a state responsibility that demanded ever-growing proportions of government budgets. As overall levels of education across the world expanded, it became the norm for young generations first to have at least primary schooling, then lower secondary schooling, then upper secondary schooling, and now university degrees. Because unit costs are greater at higher levels of education, this expansion imposed ever stronger burdens on government budgets.

Towards end of the 20th century, however, and accelerating in the 21st century, a global shift brought changed perceptions on the role of the state associated with the forces of neoliberalism and privatisation (Bhopal \& Shain, 2017; Harvey, 2005; Walford, 2016; Ward, 2014). Ball and Youdell (2008) distinguished between endogenous privatisation in which schools were made more businesslike, and exogenous privatisation in which schools contracted out services such as school meals and transport through public-private partnerships. The era also brought marked increases in the numbers of private schools. Ball and Youdell's commentary overlooked the role of shadow education, but many others have employed lenses of neoliberalism to explain aspects of its expansion (e.g. Doherty \& Dooley, 2018; Gupta, 2019; Holloway \& Kirby, 2020). Neoliberalism was to some extent a convenient ideology to offload some state responsibilities in the name of efficiency.

Among the challenges of the rapid expansion of schooling has been a sacrifice of quality (see e.g. Bown, 2009; UNICEF, 2019; World Bank, 2006). In some countries the demand for shadow 
education has been fuelled by this factor (see e.g. Rana, Sen, Sarkar, Haldar, \& Nandy, 2009). Governments are mindful of the issues, but have the challenges on the one hand of budgetary constraints and on the other hand of political pressure for further expansion of education as expectations rise. Over half a century ago, Abernethy (1969) wrote about "the political dilemma of popular education," taking the case of Southern Nigeria. Referring to schemes to universalise primary education during the 1950s, he noted the attractiveness of policies when they were launched but the tendency for backlashes when "large numbers of young people were mobilized for participation in a modern economy and polity at a time when the economy could neither employ them nor afford what was in effect a costly social welfare scheme" (p. 280). Three decades later, Buchmann (1999) made similar remarks about Kenya; and more contemporary remarks have been made by such authors as Corrales (2006), Harber (2014) and Saltman (2018). The analyses demonstrate complex relationships between quantity and quality of schooling, and raise questions about the overall integrity of education systems.

Governments concerned with integrity may feel particularly caught by competing forces when they consider the roles of teachers. Many observers would consider the ideal to be that teachers in public schools are well paid, caring, competent, and able to offer an education that in itself meets all the needs of both families and the country as a whole without supplements. However, the reality in some countries is that budgets that are stretched by educational expansion cannot provide good salaries, which forces teachers to seek alternative sources of income and legitimates them to do so. Further, once the practice of seeking such alternative sources of income becomes widespread, boundaries between public and private roles become blurred. In such circumstances, teachers operate without moral sanction and offer private supplementary tutoring even when their salaries could be considered reasonable. In societies in which neoliberal ideologies have become widely acceptable, such actions by teachers are even less likely to be challenged.

On their side, parents in competitive environments seek ways to get ahead, and then if socially acceptable directly ask teachers to provide supplements and/or go to commercial enterprises that may be partly or even fully staffed by teachers operating on a part-time basis. Then other parents are pulled into the flow, and either have to follow the majority or be left behind. Governments may be very uneasy about the matter, and especially about the practice of teachers providing private supplementary tutoring to their existing students which can raise temptations for favouritism and coercion. However, the extent to which governments can counteract these forces - i.e. swim with sufficient strength against the tide - depends in large measure on wider economic and cultural factors.

\section{SPECIFIC COUNTRY CASES}

Bearing in mind the broad picture sketched above, it is useful to compare patterns in a number of countries. The four selected - Korea, Mauritius, Kenya and England - have diverse cultures and histories and are geographically distant from each other. Two of them - Korea and Mauritius - have long had very prominent shadow education sectors, while in the other two the phenomenon on a large scale is more recent. The authorities in the first three have worked hard to limit the scale of shadow education, both in general and with specific reference to the parttime supplementary activities of teachers in government schools, but their counterparts in England have to date had a laissez faire approach. 


\section{Korea}

Contemporary institutions for private tutoring, known as hagwons, can trace their history as private schools for several centuries (Sorensen, 2019: 10-11). However, these seem to have been alternative institutions for learning rather than supplementary ones. Kim (2016: 15-16) noted the existence of hagwons for supplementary education at the outset of the 20th century, but added that the 1910 annexation of Korea by Japanese colonialism led to suppression of the institutions and caused most supplementary education to go underground.

Shadow education expanded after Korea's 1948 independence, in part because of the removal of constraints by the colonial regime. Regular teachers in government schools were among the major providers of shadow education. The matter became a significant political issue during the 1950s in the context of stress associated with examinations for entry to middle schools, high schools and universities. Increasing numbers of schools were organising fee-paying classes at weekends and in the evenings, gaining revenue both for the institutions and their teachers. In 1955, Korea's President issued a prohibition. He declared that persons failing to comply "would receive the full penalty of the law" (quoted by Seth, 2002: 143), but the prohibition could not be enforced. As Seth remarked (p. 143), the measure initiated a pattern that continued for the next four decades "of periodically banning extra classes and then lifting the bans after admitting their ineffectiveness".

Recognising that quenching demand would be a major step towards reducing supply, in 1969 the authorities in the capital city replaced the entrance examination to middle schools by a random lottery (Kim, 2004: 9). This measure was followed in other major cities in 1970 and in the rest of the country in 1971, and was accompanied by enrolment expansion to achieve nine years of compulsory education. It did have a short-term impact on private tutoring provided both by hagwons and by individual teachers, but the enrolment expansion just moved the watershed to the next level. Further, schools had to handle greater mixes of learning levels, and ambitious families that felt inadequately served resorted to private tutoring to meet their needs.

The next step, therefore, was a further lottery to allocate high school places, launched in Seoul and Pusan in 1974 and by 1980 in another 18 cities. The 1974 initiative was accompanied by a 'Plan for Normalization of Education and Remedy for the Overheated Demand for Private Tutoring' that again prohibited shadow education (Kim, 2016: 21). However, the lottery and associated policies only again moved the watershed from high school admission to university entrance. Further, the latter was of such importance that it had its own backwash to middle schooling and primary with the result that private tutoring was sustained (Kim, 2016: 22).

The year 1980 was a major political transition with the ascendance of an authoritarian military government. Able to employ extreme measures with a new degree of fierceness, the regime banned all extra high-school classes and individual private tutoring in academic subjects (Lee, Lee, \& Jang, 2010: 101). Again, however, the prohibition proved impossible to enforce. As recounted by Seth (2002), it was an open secret that private tutoring provided the main income for many college students and an important supplement for many teachers. He added (p. 186) that:

Parents went to great lengths to avoid the regulations against private tutoring.... Some families rented out apartments to tutors so that they could offer lessons to the children of one or more families without drawing the attention of the apartment watchmen. Resorts and hotels, as well as condos, often housed secret cram schools. 
The need for secrecy increased the unit costs; and since the ban only attacked the symptoms, after an initial decline the proportions of students receiving tutoring rose again. By stages, the government had to relax the ban, and expanding household incomes during the 1990s further fuelled demand and therefore supply.

Partly because of this escalation and the associated stresses and social inequalities, a new (civilian) President declared in his 1998 inaugural address that he would "free young people from extracurricular activities and relieve parents from the heavy monetary burden of private tutoring" (quoted by Yi, 2002: 2). The government announced stages for banning extra tutoring for secondary students: in 1999 for middle-school students and first-year high-school students, and in 2001 for all secondary students. However, critics again observed that the measure failed to reduce demand. As one mass-circulation periodical (Asiaweek, 1997) had stated with reference to a related 1997 initiative by the local government in Korea's capital city:

For Korean authorities to address their own shortcomings in primary and secondary education by banning tutors is a bit like trying to eliminate robbery by ensuring that the entire population is poor. In an increasingly competitive Asia, it makes no sense at all to legislate in favor of the lowest common denominator.

The periodical accurately forecasted that: “The ban's failure is as predictable as it is noteworthy. It has not worked in the past and will not work in the future." Indeed, in 2000 the courts declared the ban unconstitutional on the grounds that prohibition of receipt of supplementary tutoring infringed parents' and students' rights (Lee et al., 2010: 101).

Since that time, the Korean authorities have devised multiple measures to reduce demand for shadow education by strengthening the school system, offering free lessons through public broadcasts, further tinkering with selection mechanisms for the transition points, establishing career counselling centres, and providing after-school programmes. However, demand has remained high: still in 2018 according to official statistics $82.5 \%$ of elementary-school, $69.6 \%$ of middle-school, and $65.2 \%$ of general-high-school students were receiving private supplementary support (KOSIS, 2020). This demand was not fuelled so much by unemployment, which in general was low, but by stratification of employment. Competition was fierce to secure the stable, high-income jobs, and the major route to these jobs was through the elite universities which were themselves served by the prestigious high schools that were in turn served by prestigious middle schools and elementary schools. Shadow education provided an avenue to access these prestigious schools, and with varying degrees of quantity and quality was more or less required by the whole system.

For the focus of the present paper, however, a major contemporary difference from earlier eras is that most private tutoring is provided by hagwons and also by informal providers such as university students and retirees rather than by teachers in regular schools.

\section{Mauritius}

According to Foondun (2002: 488), records of private tutoring in Mauritius can be dated from 1889 in what was then the only state secondary school for boys. Foondun did not indicate who provided the tutoring, but it seems likely that the providers included serving teachers. In 1911 the role of teachers was made explicit in a remark by a school head who complained (quoted in Mauritius, 1994, pp. 1-2) that 12 of his staff were giving 13-33 hours of private tutoring per week. The head continued: 
To interdict this practice altogether is impossible unless adequate compensation is granted, nor do I think such a measure desirable. Gentlemen have a right to utilise their leisure out of the college hours as they think fit and I do not see who can stop them. It seems to me equally impossible to impose a limitation.... I quite admit the evil, but I am unable to suggest a satisfactory solution.

Three decades later, the author of a 1941 report (cited by Joynathsing, Mansoor, Nababsing, Pochun, \& Selwyn, 1988: 62-63) considered it "impossible for a teacher to be efficient at his work if he is doing two extra hours teaching every night from Monday to Friday," and recommended that "such coaching for the few backward boys as is necessary should be by the class teacher as part of the duty for which he is paid a salary." The author added that private coaching was "almost universal among the boys, and competition keeps it so; for if one boy has a private coach, his rival must have one too".

A further four and a half decades later, the government addressed issues with a White Paper specifically focused on the matter (Mauritius, 1984). Subsequent government-initiated research found that in 1986 across the country proportions of sampled primary students receiving tutoring rose from $11.2 \%$ in Grade 1 to $72.7 \%$ in Grade 6 in preparation for the Certificate of Primary Education examination (Joynathsing et al., 1988: 31). Proportions fell to $37.3 \%$ in secondary Form 1 (Grade 7), but then reached 87.2\% in Form 6 (Grade 12) as the Higher School Certificate examination approached (p. 43). Over three quarters of primary school children receiving tutoring did so from their own teachers. Secondary-level tutoring was commonly provided by subject specialists who were not necessarily from the students' own schools, and was generally provided in the teachers' homes or in rented premises.

Following this study, which sparked much debate, in 1988 the Minister of Education proposed a set of regulations to prohibit tutoring in Grades 1-3. He was concerned not only about the ambiguous and potentially corrupting roles of teachers but also about social inequalities and health of young children in settings of excessive academic study from both schooling and tutoring (Parsuramen, 2007: 10). However, the Minister decided to permit the use of classrooms for private tutoring in Grades 4-6 in order to allow the activity to be conducted in an appropriate environment rather than in teachers' homes, converted garages and other unsuitable premises. During the parliamentary debate that led to legislation in 1991, opposition members highlighted the risk of creating a category of teachers in Grades 4-6 who were permitted to provide tutoring while their colleagues in Grades 1-3 were not. Nevertheless, the bill was approved. It did dampen the phenomenon in Grades 1-3, but a 1994 UNICEF report observed (p. 35) that it was still "common practice at the beginning of [Grade 4] for the teacher to send a note to the parents announcing the beginning of private tuition by himself or herself to his/her own pupils." The report added that many teachers "offer group private tuition to their own classrooms, so that groups of up to 40 children will stay on and pay their teacher to give them the quality tuition they should have been receiving in school hours." Reviewing accomplishments during his long period of office (19831995), the Minister remarked on the challenges of changing attitudes and structures (Parsuramen, 1997: 41). Specifically on the topic of private tutoring, the Minister highlighted successes from persistent efforts, including that private tutoring had been prohibited for children in Grades 1-3 and that parents had been "sensitized on the abuses of excessive private tuition" (p. 43). However, he recognised that challenges remained, and waited to see what new measures his successor would take "to deal with this complex issue".

The new Minister did show willingness to take up the cause, and the issue entered the agenda again in 1997 with another White Paper. This document highlighted the way that "the super 
competitive education system" led to private tutoring (Mauritius, 1997: 28). It avoided what it called drastic solutions, but did envisage prohibition of tutoring on school premises. However, political shifts undermined these proposals. During the Minister's absence on an overseas visit, the Cabinet overturned the policy.

Nevertheless the next leadership, commencing in 2000, again took up the theme. Among its flagships was a document evocatively titled Ending the rat race in primary education (Mauritius, 2001). The government sought to ease the bottleneck by expanding access to high quality secondary education. Reviewing his period of office (2000-2005) the Minister, though recognising a lack of data, later claimed that his reforms had reduced the pressure for private tutoring (Obeegadoo in Mauritius, National Assembly, 2011: 100). Yet a 2006 review indicated that parents still felt that their children would be disadvantaged if they did not receive private tutoring. It added (Bah-lalya, 2006: 75) that some teachers had produced textbooks that pupils were encouraged to buy as part of private tutoring, and that such teachers could "more than double their salaries with private tutoring and the royalties earned from their books." A 2007 national survey indicated that $74.6 \%$ of Grade 6 students were receiving shadow education (SACMEQ, 2010: 1). The bulk of this shadow education was provided informally by regular teachers, and Mauritius had relatively few specialist companies dedicated to such work.

In 2009, again under new leadership the Ministry announced that the prohibition of private tutoring for children in Grades 1-3 would be extended to Grade 4, adding that school hours would be lengthened and school holidays reduced (Mauritius, 2009: 65). The teachers' unions immediately expressed strong dissent (Hilbert, 2009). The proposal led to vigorous debate in the parliament (Mauritius, National Assembly, 2011), but the government pushed through with legislation (Mauritius, Government of, 2011) accompanied by an Enhancement Programme to extend in-school teaching on the grounds that it would reduce the need (and time available) for private tutoring. The teachers demanded extra salaries for the extra in-school work, which were granted.

This prohibition of tutoring in Grades 1-4 did appear to have dampened the phenomenon even though much tutoring for these grades went underground. Nevertheless, data collected in 2013 from a representative national sample of Grade 6 students indicated that $81.4 \%$ were receiving private tutoring (Dwarkan, 2017: 37). Data were not collected for Grade 5 or for secondary grades, but certainly the phenomenon was also significant at those levels. In 2014, the Ministry proposed to register teachers wishing to provide tutoring from Grade 5 upwards, set the maximum number of students per group, and restrict the frequency, duration and timing in which tutoring could be delivered (Mauritius, 2014: 66). The Minister had desired to extend the prohibition to Grades 5 and 6, but his period in office concluded before he could formally propose that, and the other proposals were also shelved. Towards the end of his term the Minister recognised that "it takes a lot to change mindsets and move away from the comfort of the status quo" (Bunwaree, 2014: iii).

Reviewing the matter once again, a 2019 critique by a non-governmental organisation called Think Mauritius described private tutoring as "a parallel system of education with a turnover of billions of rupees, endorsed and supported by Teacher Unions for the benefit of their members" (Think Mauritius, 2019, p. 15) and as "a symptom of a diseased education system" (p. 42). The solution, the report suggested (p. 42) would be "to go to the root of the problem and to revisit the whole system" with particular emphasis on reducing the role of examinations, placing curriculum development at the centre of the reform programme, and consolidating teacher 
training and school management. However, all these measures had been considered before. Various reforms had changed the labels but had not resolved issues of stratification in the education system and labour market (Samuel \& Mariaye, 2020). Mauritius clearly had no simple solution given the long history of private tutoring and the way in which it was embedded in the culture. Successive governments had considered the root of the problem, but had met vested interests that could not easily be overturned.

\section{Kenya}

Kenya appears to have a shorter history of shadow education compared with Korea and Mauritius, but the phenomenon seems to have been evident at least since the 1970s. This may be presumed from the fact that in the 1980s the Ministry of Education issued a circular (Kenya, 1988) directing teachers to cease providing private tuition (as tutoring is more commonly labelled in Kenya). The Ministry's circular was greeted with scepticism by an editorial in the main English-language newspaper (Daily Nation, 1988). The newspaper recognised the social and educational issues arising from tutoring, but added that Kenyans had heard so many times about government disapproval and even prohibition "that it is beginning to ring hollow." The newspaper predicted that schools (and therefore teachers) would continue with private tuition and get away with it. "This is because there are no systems to enforce the rule," and also "because the practice has been entrenched by the dynamics of the day."

The newspaper was proven right. Buchmann (1999: 107) provided some numbers through a 1995 survey of 597 households in Nairobi, Kwale and Murang'a. She found that tutoring was most common in the later years of primary schooling when students prepared for the Kenya Certificate of Primary Education, and especially in urban areas. In her Nairobi sample, 55.6\% of children received private tutoring compared with $30.0 \%$ in Kwale and 27.0\% in Murang'a. The costs varied widely according to the charges demanded by the tutors and the durations of tutoring received by the children, but Buchmann calculated (p. 115) that on average one year of tutoring for one child could cost one-seventh of the average household income. Tutoring was organised by teachers in their schools not only during evenings and at weekends but also during school holidays (Andrew, Saina, Kimurgor, \& Taalam, 2016: 65; Buchmann, 2002: 142).

The next policy initiative was a 1999 restatement of prohibition of extra classes during evenings and week-ends and also during holidays (Mogaka, Gunga, Juma, Monanda, \& Owino, 2016: 9). Again, however, the practices continued with little impediment, and a 2007 national survey found that $46.3 \%$ of Grade 6 pupils were receiving shadow education (SACMEQ, 2010: 1).

With such matters in mind, in 2008 the Ministry of Education issued a new prohibition of holiday tuition which even gained international attention (BBC, 2008). That international news report claimed that the measure had been welcomed by the National Parents' Association, the Kenya National Union of Teachers, and the Kenya Secondary Schools Heads Association; but in practice the policy raised much discontent among teachers and families. Further, the fact that in 2012 the Minister for Education felt it necessary to repeat the prohibition (Daily Nation, 2012a) again showed that the activities had continued.

On the occasion of this 2012 initiative the Minister was adamant, declaring in a news broadcast that he had "criminalised holiday tuition" (Mogaka et al., 2016: 10). The Minister certainly had some support. For example, one correspondent in the Daily Nation (Buhere, 2012) stressed the need "to let go our hold on young learners so that they can have the freedom to be 
children." However, others were more critical. The Kenya National Union of Teachers stated that the Minister had failed to question why the practice continued unabated, and declared that when you ban tuition in schools "it will resurface in the private centres at homes and towns" (Daily Nation, 2012b). The commentator added that when the Minister took it upon himself to impose the ban, he failed "to deal with the root issues of why it takes place and address them." The Minister was unrepentant, however, and when the new academic year commenced in September he extended the prohibition from holiday classes to weekend classes (Otieno, 2012). By this time the political atmosphere was so tense that the teachers went on strike.

In due course the strike was resolved through negotiation, and during political shifts in 2013 the Minister was changed. Nevertheless, the issue was resurrected in 2015 (Daily Nation, 2015) when the Education Cabinet Secretary again confronted the matter. He pointed out that holiday tuition had been outlawed under the 2013 Basic Education Act (Kenya, 2013; section 37), which stated that "Any person who contravenes [the provision] commits an offence and is liable on conviction to a fine not exceeding one hundred thousand shillings or to imprisonment for a period not exceeding one year or to both". ${ }^{2}$ Nevertheless, both holiday and term-time tutoring continued, still with media attention. A 2018 newspaper report included a picture of a teacher being arrested two years previously, but highlighted the tutoring that continued for both secondary and primary students in schools, churches and homes. It added that in the location investigated by reporters, parents "revealed that the lessons are mandatory for students in class seven and eight and there is a penalty for parents who fail to allow their children to attend the lessons charged between Sh350 to Sh1,000" (Daily Nation, 2018). Thus, fundamental issues that the authorities had tried to confront were clearly ongoing.

\section{England}

The English context is very different, but is instructive for juxtaposition because recent years have brought far-reaching shadow education in which regular teachers play a significant role. Ireson (2004: 110) observed that private tutoring in the United Kingdom (UK) had long been a respectable and valued supplementary occupation for university students and teachers, and she also noted the existence of 'cram' schools that helped students to improve their grades in national examinations. However, she added, "available evidence indicates that ... the extent of shadow education in the UK is relatively low" (p. 118).

Seeking to reduce this evidence gap, Ireson and Rushforth (2005) surveyed 3,615 pupils in 64 schools across England and found that proportions were much greater than many people had anticipated. When Year 13 students were asked if they had ever received tutoring, 29.5\% replied affirmatively, while $26.0 \%$ of students in both Year 11 and Year 6 did so. Mathematics was the most popular subject, in which $18.6 \%$ of Year 13, 17.5\% of Year 11, and 16.9\% of Year 6 students were receiving tutoring at the time of the survey.

These figures resonated with subsequent annual surveys conducted by the Sutton Trust. The 2018 iteration, for example, indicated that $27 \%$ of sampled students in England and Wales aged 11-16 had received private tutoring at some time, with this number rising to $41 \%$ in London (Sutton Trust, 2018). Even more pertinent to the present paper, the 2019 iteration surveyed

\footnotetext{
${ }^{2}$ At the average 2012 exchange rate, KSh100,000 was equivalent to US $\$ 1,183$. World Bank data indicated an annual per capita Gross Domestic Product of US\$1,153.
} 
teachers as well as students. When asked if they had ever provided paid tutoring outside their schools, $24 \%$ of secondary and $14 \%$ of primary teachers replied affirmatively (Sutton Trust, 2019).

Addressing the question what lay behind such patterns, Reed (2018: 36-41) identified four factors. She commenced with the changes made by the right-wing Conservative government between 1979 and 1997, including the marketisation of education and greater parental choice of schools. Private schooling had been given greater legitimacy, and increasing numbers of parents unable to fund private schooling had sought private tutoring to supplement state provision. Second, the government's raising of the school-leaving age to 16 meant that students who had traditionally left school for employment at an earlier age had been obliged to continue their studies. One outcome was that students who would not traditionally have pursued academic studies had to do so, and some needed private tutors for remedial assistance. Also, increased numbers of students in post-16 education expanded competition for which private tutoring provided support.

A third further influence, evident in many countries, concerned parenting styles. One dimension was the rise of 'helicopter' parents ready to swoop for protection of their children when needed (Hunt, 2008), and of 'lawnmower' parents providing similar services by removing barriers to success (Locke, Campbell, \& Kavanagh, 2012). Technological developments exacerbated these styles, with parents able both to contact teachers and tutors with greater immediacy and to monitor their children more closely. Not mentioned by Reed but also pertinent were parents' online chat groups that both raised anxieties and provided tutoring as a possible solution.

Fourthly, Reed focused on examinations, especially those at the watershed ages 11, 16 and 18 . Ireson and Rushforth (2014: 21), focussing on parental demand for tutoring, had found that "success in examinations was the most important reason for investment, ahead of improved understanding of the topic and increased self-confidence." The authorities had introduced possibilities to resit examinations as a way to reduce stress, but had found that this reduced the extent to which students took responsibility for their own learning, and in 2015 reverted to previous arrangements in which resitting was less straightforward (Reed, 2018: 41). Like counterparts around the world, the English authorities found it difficult either to replace the examinations or to reduce the stresses from the examinations at transition points.

Of course supply also fuelled demand. As in other parts of the world, much tutoring was also provided not only by teachers but also by commercial agencies, university students and others. Nevertheless, for the focus of the present paper on the roles of serving teachers, an investigation by The Guardian newspaper is pertinent (Weale, 2018). The report "revealed the appeal of private tuition for teachers, whose salaries have been depressed for years," and added the challenge of "the one-size-fits-all approach in schools" in contrast to the greater professional freedom in tutoring. Thus the spirit and working conditions in the schools were another pertinent factor. Some frustrated teachers left the sector altogether to become full-time tutors, but others conducted both activities in parallel. The English case thus again showed growing momentum for teachers working also as tutors.

\section{COMPARING THE CASES}

Fig. 1 shows in broad terms the overlap between teachers' roles in schools and in the shadow sector in Korea's history and in contemporary Mauritius, Kenya and England. Of course the relative sizes of schooling and the shadow sector and the extent of overlap varied between and 


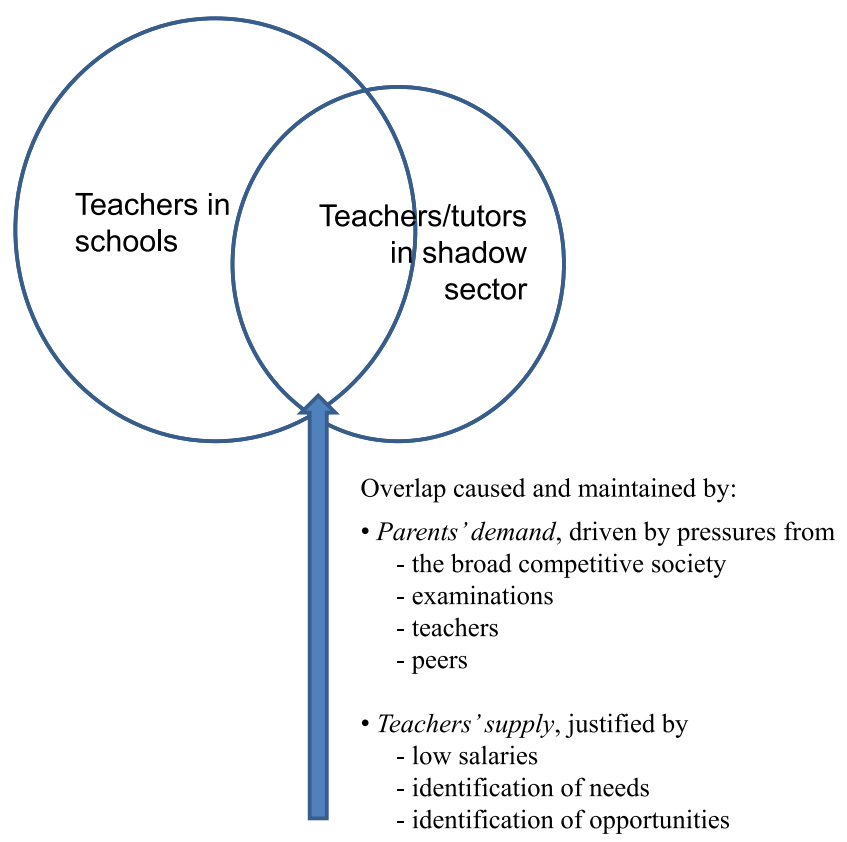

Fig. 1. Patterns in historical Korea and contemporary Mauritius, Kenya and England

within each location, in different grades, and at different points in time. Nevertheless, the model shows commonalities. Parental demand for shadow education was fuelled by competition for employment and associated dimensions and, within the education system, by watershed examinations. It was also fuelled by teachers who either explicitly recommended their students to receive private tutoring or passively assumed that their students were receiving tutoring and then themselves failed to provide as much care during schooling as they would otherwise have done. Shadow education was further consolidated by peer pressures among students and families. On the side of the teachers, pressures and justifications to supply tutoring were linked to their salary levels and also in many cases by a feeling that indeed their students needed extra support to cover the full syllabus in sufficient depth. Alongside teachers providing supplementary tutoring were university students, retirees and others operating on an informal basis, and commercial enterprises with a range of operating models.

Contemporary Korea shows a different picture, with almost all tutoring supplied by hagwons and other providers as depicted in Fig. 2. If any serving teachers provide tutoring, they do so covertly in small numbers. Four main factors permit and support this pattern. First, teachers have high salaries and thus relatively little financial need; second, teachers have substantial workloads and thus modest time and energy for additional activities; third, because of persistent government statements and internal sanctions on teachers, Korean society no longer expects teachers to provide shadow education; and fourth, the commercial sector operates as an efficient and specialised alternative that may be even more effective than provision by teachers. The Korean authorities, aided by economic growth that has permitted high salaries for teachers and by societal agreement about the problematic dimensions when teachers provided tutoring, have 


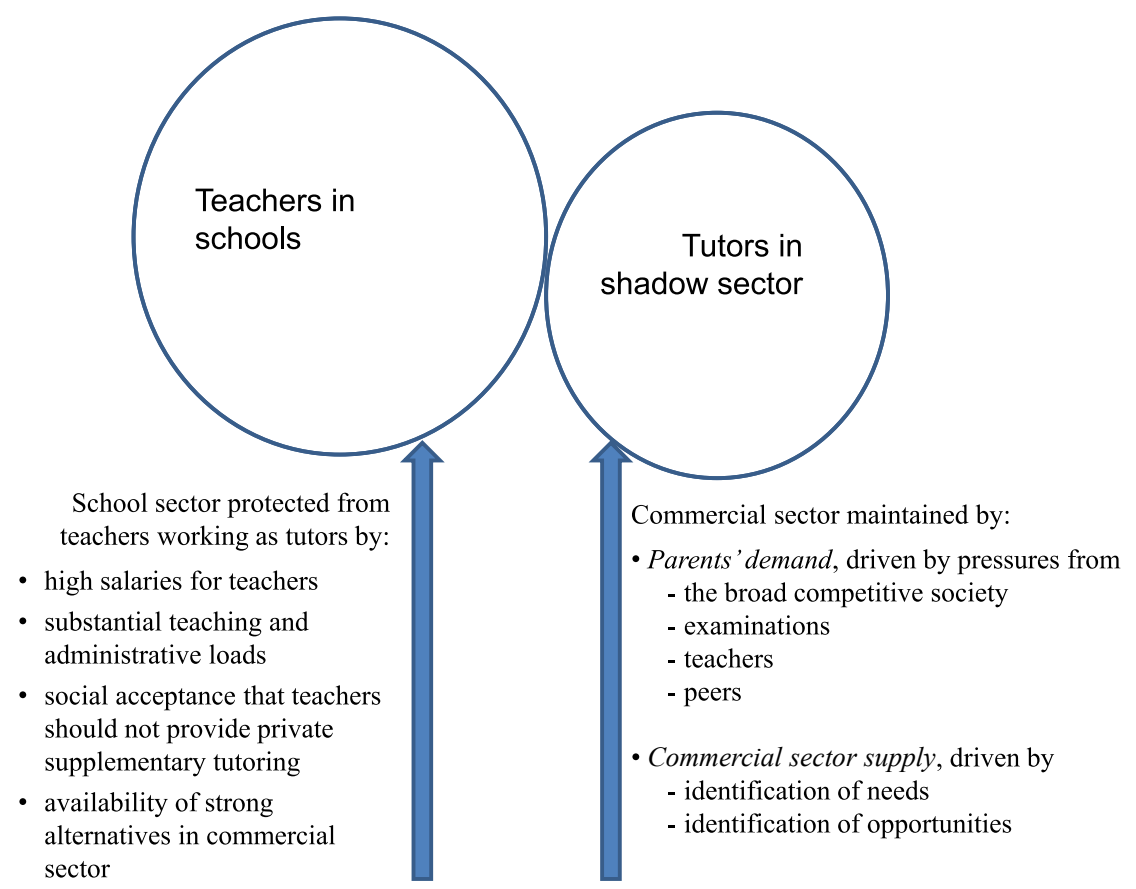

Fig. 2. Patterns in contemporary Korea

been strong swimmers against the tide. They have not achieved the wider goal of significantly reducing the overall scale of shadow education, but from the perspective of this paper Korea can nevertheless be viewed as a case to show that persistent efforts when supported by other factors can achieve the goal of minimising the tendency for regular teachers to provide private supplementary tutoring.

By contrast, enabling conditions in Kenya and Mauritius have been less favourable. Kenya has had a weak economy with high unemployment and national debt, and thus scarcity of government resources (Kaimuri \& Kosimbei, 2017); and parents have felt either that shadow education provided by teachers was desirable or that they had no choice and therefore somehow had to find the resources in a situation where private tuition was part of the system (Paviot, 2015: 149-153). Mauritian economic circumstances have been stronger (Tang, Shaw, \& Holden, 2019), but again shadow education provided by teachers is engrained in the culture. Further, both Kenya and Mauritius have strong teachers' unions that have constrained government action.

Patterns in England are rather different because the country has a long and proud history of education with universal enrolments. English parents are less likely to invest in tutoring because they have no choice than because they want to get ahead. For example one parent interviewed by Weale (2018) remarked that:

The world is very competitive and everybody is working very hard. I know the school are doing very well, but there are 30 students in each class. ... They try their best to help, but I realise if I'm going to give my kids some extra help it's going to be brilliant for their future. Anyone who does a bit extra always gets ahead. 
Yet once one family secures such extra help, the challenge is raised for others. "We are in an education arms race," said the founder of the Sutton Trust (reported by Weale, 2018), echoing the author of the 1941 Mauritian report that "if one boy has a private coach, his rival must have one too".

\section{CONCLUSIONS}

This paper has stressed that shadow education is not a new phenomenon. In Korea, Mauritius and England, its history can be traced to the early 20th century or before; and even in Kenya it has a history of at least four decades. However, shadow education has only recently become a significant focus for research. This is chiefly because it has now greatly expanded across the globe (Aurini et al., 2013; Bray, 2009; Park, Buchmann, Choi, \& Merry, 2016).

The principal commonality among the four cases examined in this paper - and indeed throughout the world - lies in the roles and aspirations of families. Parents in all cultures want the best for their children, and see education as an avenue for social advance. In the four countries addressed, private supplementary tutoring was initially sought mainly by upper-class families; but with the expansion of access to education, middle-class and even lower-class families entered the picture. Both family and government investments in education have sometimes led to disappointing outcomes. Writing about the disjunctions between expanded education and lack of employment opportunities in Kenya, Buchmann (1999: 96) asserted that "now, over three decades after independence, there are clear signs that Kenyans' faith in education is faltering." History has not supported Buchmann's statement, however, as evidenced in the huge financial investments that Kenyan families have continued to make. The continued existence of private supplementary tutoring during both term time and school holidays reflects an ongoing willingness by families to pay. Similar remarks apply elsewhere across the globe.

At the other end of the scale of geographic remit by individual families are the international agencies. At the time of the 1948 United Nations Universal Declaration of Human Rights, England already had high rates of school enrolment and was a shaper rather than a recipient of the advocacy that brought universalisation of basic education around the world. Among the other three countries, perhaps Kenya has been most influenced by UNESCO advocacy of universal basic education, receiving support also through the World Bank and bilateral donors. Mauritius was in a similar category, while Korea which in the 1940s and 1950s had been a poor country achieved remarkable economic growth - to some extent underpinned by both mainstream and shadow education - and in 1996 became an OECD member. Nevertheless, even Korea found itself receiving similar advice over the decades. Thus Seth (2012: 23) commented on a 1952 UNESCO report that had been highly critical while expressing admiration for Korean zeal in education, and then noted a 1998 OECD report that sounded in some respects remarkably similar. The international agencies continue to advocate expansion of education, accompanied by qualitative improvement. This is despite many macro-level disappointments about the impact of education in the domains of the labour market, changed mindsets, and mutual respect to which the United Nations Deputy Secretary General, quoted above (Mohammed, 2020), referred so positively.

Alongside micro-level households and global organisations are governments, with their politicians who are required both to lead and to serve. Government in all countries face tensions in this domain, and Abernethy's remarks about the political dilemma of popular education in 
Southern Nigeria to a large extent also apply elsewhere. Seth's (2002: 5) review of Korean history noted "the continual, and to a considerable extent unsuccessful, attempts by the state to coordinate education with economic development needs." Buchmann (1999: 96) similarly observed that governments are commonly "forced to react to the demands of local communities in ways that are politically expedient in the short term, rather than pursue initiatives that are in the long-term national interest"; and Bown's (2009) review of lessons from campaigns of fee-free primary education in Ghana, Kenya, Nigeria, Tanzania and Zambia noted the short-term political appeal of such schemes but that they could not easily be maintained because of financial and other constraints. Shadow education was a way in those countries and in others such as Cambodia and India (Bray et al., 2018; Gupta, 2019) to maintain the façade of fee-free education while actually allowing (or in effect requiring) families to make substantial payments.

Addressing further the broad literature with which this paper commenced, some analysts (e.g. Doherty \& Dooley, 2018; Gupta, 2019; Holloway \& Kirby, 2020) have linked the expansion of shadow education to the global acceptance of neoliberalism in the education sector. While this perspective has much validity, it needs some nuances. First, the history of shadow education in Korea and Mauritius long precedes the advent of the sweeping neoliberal ideology towards the end of the 20th century; and second, in Korea the contemporary existence of shadow education is maintained despite the ongoing strong role of the state. Nevertheless, it is true that patterns in England have been facilitated by the neoliberal acceptance of the role of the private sector in education (Ball \& Youdell, 2008; Reed, 2018); and in settings where the state desires to remain at least the major provider one if not the sole one, neoliberal dynamics may still be vigorous at the local and household levels. The latter case is evident in China, for example, where forces that support and expand the shadow education sector may be described as micro-neoliberalism (Zhang \& Bray, 2017). This perspective helps to explain the rise and maintenance of shadow education even in education systems that are well resourced by their governments.

Nevertheless, to return to the main title and central theme of this paper, strong reasons can be advanced for discouraging and even prohibiting regular teachers from providing private supplementary tutoring. Governments that wish to take such a line then have to swim against the tide of other forces. Parents look after their own self-interest, including by soliciting extra support from teachers if permitted to do so; and teachers, supported by their unions, may feel that they have a right to provide the service and that it is morally acceptable to do so. The teachers' arguments are bolstered when they consider their salaries to be low, whether or not that is a verifiable fact; and in many cases teachers also justify their behaviour through concern to support learners in need.

Governments that decide to tackle this issue would be wise to commence with consideration of the background factors that underlie both demand for and supply of private tutoring. If they do decide to tackle the roles of teachers, governments would be strategic to engage with the unions, perhaps appealing to broader values of social service in place of narrower self interest. Governments should also consider the extent to which regulations can be enforced, since failure to do so erodes legitimacy. In this respect, the Mauritian authorities were arguably wise for some decades to avoid trying to prohibit teachers from providing tutoring when they could not enforce such a prohibition. Eventually the Mauritian government did prohibit tutoring for students first in Grades 1-3 and then in Grade 4. Even this was controversial, and some tutoring simply continued underground, but the early grades were the easiest to tackle since they were furthest from the watershed examinations. The authorities stopped short of trying to prohibit 
teachers of higher grades from providing tutoring, which demonstrated recognition that some compromises were necessary.

More positively, the Korean example shows that persistence can deliver results when supported by a strong economy and other elements. However, the Koreans authorities themselves continue to lament the overall scale of shadow education, and in that respect although teachers no longer overtly provide private tutoring the Korean government would hesitate to describe itself as a model for other countries. This remark again shows the need for forms of compromise and accommodation.

This paper has shown that much can be learned from comparative analysis about both the possibilities for government action and the constraints. Among the certainties for all four countries examined is that the basic tensions will not disappear. In England, the founder of the Sutton Trust remarked (quoted in Weale, 2018) that "Tutoring is huge, it's getting bigger and it's not going away." That general message should also be heard in other countries around the world. Shadow education may change shape in response to government policies and other economic and social factors, but it will not go away. Governments in countries where teachers are already providing much tutoring should examine themes in a comprehensive way to determine avenues for persuasion and to ameliorate issues; and their counterparts in countries where shadow education is less prominent would be wise to steer forces before they become firmly consolidated.

\section{REFERENCES}

Abernethy, D. B. (1969). The political dilemma of popular education: An African case. Stanford: Stanford University Press.

Andrew, K., Saina, C., Kimurgor, B. J., \& Taalam, B. (2016). Teachers' justifications for the need for school holiday coaching in Kenya: Syllabus coverage and other factors. International Journal of Academic Research and Development, 1(9), 61-68.

Asiaweek. (1997). Banning tutors: In education-obsessed Asia, the move is both wrong and futile. [Editorial]. 23(17), 2 May. http://edition.cnn.com/ASIANOW/asiaweek/97/0502/ed2.html.

Aurini, J., Davies, S., \& Dierkes, J. (Eds.). (2013). Out of the shadows: The global intensification of supplementary education. Bingley: Emerald.

Bah-lalya, I. (Ed.), (2006). Mauritius: 2000-2005 educational reform. Paris: UNESCO International Institute for Educational Planning (IIEP).

Baker, D. P. (2014). The schooled society: The educational transformation of global culture. Stanford: Stanford University Press.

Ball, S. J., \& Youdell, D. (2008). Hidden privatisation in public education. Brussels: Education International. BBC [British Broadcasting Corporation]. (2008). Kenya bans holiday tuition, 13 August. http://news.bbc.co. uk/2/hi/7558078.stm, accessed 23 February 2020.

Benavot, A., \& Resnick, J. (2006). Lessons from the past: A comparative socio-historical analysis of primary and secondary education. In Cohen, J. E., Bloom, D. E., \& Malin, M. B. (Eds.), Educating all children: A global agenda (pp. 123-219). Cambridge, MA: American Academy of Arts and Sciences and MIT Press.

Bhopal, K., \& Shain, F. (Eds.). (2017). Neoliberalism and education: Rearticulating social justice and inclusion. London: Routledge. 
Bown, L. (2009). Lessons for the future. In L. Bown (Ed.), Maintaining universal primary education: Lessons from commonwealth Africa (pp. 124-143). London: The Commonwealth Secretariat.

Bray, M. (2003). Adverse effects of supplementary private tutoring: Dimensions, implications, and government responses. Series: 'Ethics and corruption in education'. Paris: UNESCO International Institute for Educational Planning (IIEP).

Bray, M. (2009). Confronting the shadow education system: What government policies for what private tutoring?. Paris: UNESCO International Institute for Educational Planning (IIEP).

Bray, M., Kobakhidze, M. N., Zhang, W., \& Liu, J. (2018). The hidden curriculum in a hidden marketplace: Relationships and values in Cambodia's shadow education system. Journal of Curriculum Studies, 50(4), 435-455.

Buchmann, C. (1999). The state and schooling in Kenya: Historical developments and current challenges. Africa Today, 46(1), 95-117.

Buchmann, C. (2002). Getting ahead in Kenya: Social capital, shadow education, and achievement. In B. Fuller, \& E. Hannum (Eds.), Schooling and social capital in diverse cultures (pp. 133-159). Oxford: Elsevier.

Buhere, K. (2012). Extra tuition robs learners of freedom to be children. Letters section. Daily Nation, 4 August. https://www.nation.co.ke/oped/Letters/Extra+tuition+robs+learners + of +freedom+to+be + children/-/ 440806/1471186/-/v5ro3o/-/index.html.

Bunwaree, V. K. (2014). Foreword. In Mauritius, Ministry of education \& human resources. Education reforms in action 2008-2014: Learning for life. Port Louis: Ministry of Education \& Human Resources.

Corrales, J. (2006). Political obstacles to expanding and improving schooling in developing countries. In J. E. Cohen, D. E. Bloom, \& M. B. Malin (Eds.), Educating all children: A global agenda (pp. 231-299). Cambridge, MA: American Academy of Arts and Sciences and MIT Press.

Daily Nation. (1988). Banning private tuition a futility, 14 August. https://www.nation.co.ke/oped/ Editorial/-/440804/456488/-/qm5bmiz/-/index.html.

Daily Nation. (2012a). Kilonzo issues tuition warning, 24 July. https://www.nation.co.ke/news/ Kilonzo+issues+tuition+warning+/-/1056/1461868/-/b21gns/-/index.html\%20208.

Daily Nation. (2012b). Teachers criticize education minister Kilonzo tuition directive, 15 August. http:// www.nation.co.ke/News/Teachers-criticise-Kilonzo-tuition-directive-/-/1056/1480224/-/iwnfff/-/index. html.

Daily Nation. (2015). Allow holiday tuition at own risk, education officials warned, 2 August. https://www. nation.co.ke/news/No-holiday-tuition-in-schools/1056-2817004-qpxcqcz/index.html.

Daily Nation. (2018). Schools secretly offer holiday tuition despite ban, 24 April. https://www.nation.co.ke/ news/education/Schools-secretly-offer-holiday-tuition-despite-ban-/2643604-4495274-tbv8fsz/index. html.

Dawson, W. (2009). The tricks of the teacher: Shadow education and corruption in Cambodia. In S. P. Heyneman (Ed.), Buying your way into heaven: Education and corruption in international perspective (pp. 247-264). Rotterdam: Sense.

Doherty, C., \& Dooley, K. (2018). Responsibilising parents: The nudge towards shadow tutoring. British Journal of Sociology of Education, 39(4), 551-566.

Dwarkan, L. (2017). SACMEQ IV study Mauritius: A study of the conditions of schooling and the quality of education. Port Louis: Southern and Eastern Africa Consortium for Monitoring Educational Quality (SACMEQ).

Entrich, S. R. (2018). Shadow education and social inequalities in Japan: Evolving patterns and conceptual implications. Cham: Springer. 
Foondun, R. (2002). The issue of private tuition: An analysis of the practice in Mauritius and selected South-East Asian countries. International Review of Education, 48(6), 485-515.

Graveleau, S. (2020). Ces enseignants qui ont un deuxième metier [These teachers who have a second job]. Le Monde, 11 February. https://www.lemonde.fr/societe/article/2020/02/11/ces-enseignants-qui-ontun-deuxieme-metier-apres-la-classe_6029143_3224.html, accessed 4 March 2020.

Gupta, A. (2019). Teacher-entrepreneurialism: A case of teacher identity formation in neoliberalizing education space in contemporary India. Critical Studies in Education. https://doi.org/10.1080/17508487. 2019.1708765.

Harber, C. (2014). Education and international development: Theory, practice and issues. Oxford: Symposium.

Harvey, D. (2005). A brief history of neoliberalism. New York: Oxford University Press.

Hilbert, P. (2009). Abolition des leçons en Std. IV: la guerre ouverte [Abolition of (private) lessons in standard IV: The open war]. L'Express, 26 May.

Holloway, S. J., \& Kirby, P. (2020). Neoliberalising education: New geographies of private tuition, class privilege, and minority ethnic advancement. Antipode: A Radical Journal of Geography, 52(1), 164-184.

Hunt, J. (2008). Make room for daddy. . and mommy: Helicopter parents are here!. The Journal of Academic Administration in Higher Education, 4(1), 9-11.

Ille, S., \& Peacey, M. W. (2019). Forced private tutoring in Egypt: Moving away from a corrupt social norm. International Journal of Educational Development, 66, 105-118.

Inter-Agency Commission. (1990). World conference on education for all: Final report. New York: United Nations.

Ireson, J. (2004). Private tutoring: How prevalent and effective is it?. London Review of Education, 2(2), $109-122$.

Ireson, J., \& Rushforth, K. (2005). Mapping and evaluating shadow education. End of award report, ESRC research project RES-000-23-0117. London: Institute of Education, University of London.

Ireson, J., \& Rushforth, K. (2014). Why do parents employ private tutors for their children? Exploring psychological factors that influence demand in England. Journal for Educational Research Online, 6(1), $12-33$.

Jayachandran, S. (2014). Incentives to teach badly: After-school tutoring in developing countries. Journal of Development Economics, 108, 190-205.

Joynathsing, M., Mansoor, M., Nababsing, V., Pochun, M., \& Selwyn, P. (1988). The private costs of education in Mauritius. Réduit: School of Administration, University of Mauritius.

Kaimuri, B., \& Kosimbei, G. (2017). Determinants of sustainable development in Kenya. Journal of Economics and Sustainable Development, 8(24), 17-36.

Kenya, Government of. (2013). The basic education Act, 2013. Nairobi: Government Printer.

Kenya, Ministry of Education. (1988). Guidelines on repeating classes, mock examinations and extra teaching/coaching (circular No G/9/1/115). Nairobi: Ministry of Education.

Kim, H. (2004). Analysing the effects of the high school equalization policy and the college entrance system on private tutoring expenditure in Korea. KEDI Journal of Educational Policy, 1(1), 5-24.

Kim, Y. C. (2016). Shadow education and the curriculum and culture of schooling in South Korea. New York: Palgrave Macmillan.

KOSIS [Korean Statistical Information Service] (2020). Participation rate on private education by school level and characteristics. http://kosis.kr/eng/statisticsList/statisticsListIndex.do?menuId=M_01_01\&vwcd=MT_ ETITLE\&parmTabId=M_01_01\&statId=1963003\&themaId=\#SelectStatsBoxDiv, accessed 23 February 2020. 
Lee, C. J., Lee, H., \& Jang, H. M. (2010). The history of policy responses to shadow education in South Korea: Implications for the next cycle of policy responses. Asia Pacific Education Review, 11(1), 97-108. Locke, J., Campbell, M. A., \& Kavanagh, D. J. (2012). Can a parent do too much for their child? An examination by parenting professionals of the concept of overparenting. Australian Journal of Guidance and Counselling, 22(2), 249-265.

Makwerere, D., \& Dube, D. (2019). Parental/guardian subsidization of extra tuition and the marginalisation of the poor in Zimbabwe: Social exclusion in education sector in Zimbabwe. In S. Wisdom, L. Leavitt, \& C. J. Bice (Eds.), Handbook of research on social inequality and education (pp. 383-402). Hershey, Pennsylvania: IGI Global.

Mauritius, Government of. (2011). The education (amendment) bill (No.XXV of 2011): Explanatory memorandum. Port Louis: Parliament of Mauritius.

Mauritius, Ministry of Education, Arts and Culture. (1984). White Paper on education. Port Louis: Ministry of Education, Arts and Culture.

Mauritius, Ministry of Education, Culture \& Human Resources. (2009). Education and human resources strategy plan, 2008-2020. Port Louis: Ministry of Education, Culture \& Human Resources.

Mauritius, Ministry of Education \& Human Resource Development. (1997). White paper on pre primary, primary and secondary education. Port Louis: Ministry of Education \& Human Resource Development.

Mauritius, Ministry of Education \& Human Resources. (2014). Education reforms in action 2008-2014: Learning for life. Port Louis: Ministry of Education \& Human Resources.

Mauritius, Ministry of Education \& Science. (1994). Use and abuse of private tuition. Port Louis: Ministry of Education \& Science.

Mauritius, Ministry of Education \& Scientific Research. (2001). Ending the rat race in primary education and breaking the bottleneck at secondary education. Port Louis: Ministry of Education \& Scientific Research.

Mauritius, National Assembly. (2011). Fifth national Assembly: Parliamentary debates (Hansard). No. 19, 25 October http://mauritiusassembly.govmu.org/English/hansard/Pages/Year-2011.aspx.

Mogaka, A. G., Gunga, S. O., Juma, S. N., Monanda, S. M., \& Owino, K. O. (2016). Factors that influence the need for private supplementary tuition in secondary schools: A case study of selected schools in Borabu District of Nyamira county, Kenya. International Journal of Advances in Management and Economics, 4(3), 9-20.

Mohammed, A. (2020). Speech by Amina Mohammed, United Nations Deputy Secretary-General, at highlevel interactive dialogue on the occasion of the International Day of Education, New York, 24 January. http://webtv.un.org/watch/player/6126355662001, accessed 5 March 2020.

OECD [Organisation for Economic Co-operation and Development] (2001). The well-being of nations: The role of human and social capital. Paris: OECD.

Otieno, R. (2012). Now Mutula bans weekend classes. The Standard, 10 September. http://www. standardmedia.co.ke/?articleID $=2000065870 \&$ pageNo $=1$.

Park, H., Buchmann, C., Choi, J., \& Merry, J. (2016). Learning beyond the school walls: Trends and implications. Annual Review of Sociology, 42, 231-252.

Parsuramen, A. (1997). Master plan for education for the year 2000: The Mauritian experience. Paris: UNESCO International Institute for Educational Planning (IIEP).

Parsuramen, A. (2007). The Mauritius experience (1983-1995). Presentation during IIEP policy Forum on Confronting the shadow education system: What government policies for what private tutoring?. Paris: UNESCO International Institute for Educational Planning (IIEP). 
Paviot, L. C. (2015). Private tuition in Kenya and Mauritius: Policies, practices and parents' perceptions examined from an ecological systems perspective. EdD thesis, Institute of Education, University College London.

Rana, K., Sen, S., Sarkar, M., Haldar, P., \& Nandy, A. (2009). The Pratichi education report II: Primary education in West Bengal - changes and challenges. Delhi: Pratichi (India) Trust.

Reed, C. L. M. (2018). The function and purpose of the shadow education system: An action research study of post-16 students' perceptions of private tutoring. EdD thesis University of Durham.

SACMEQ [Southern and Eastern Africa Consortium for Monitoring Educational Quality] (2010). How widespread is the provision of paid tuition in school subjects?. SACMEQ Policy Issues 7. http://www. sacmeq.org/sites/default/files/sacmeq/reports/sacmeq-iii/policy-issue-series/007-

sacmeqpolicyissuesseries-extralessons.pdf.

Saltman, K. J. (2018). The politics of education: A critical introduction (2nd ed.). New York: Routledge.

Samuel, M. A., \& Mariaye, H. (2020). Schooling education in Mauritius: Negotiated connectivities. In P. M. Sarangapani, \& R. Pappu (Eds.), Handbook of education systems in South Asia (pp. 1-31). Singapore: Springer.

Seth, M. J. (2002). Education fever: Society, politics, and the pursuit of schooling in South Korea. Honolulu: University of Hawai'i Press.

Seth, M. J. (2012). South Korea's educational exceptionalism. In N. Abelmann, J. Choi, \& S. J. Park (Eds.), No alternative? Experiments in South Korean education (pp. 17-27). Los Angeles: University of California Press.

Sorensen, A. (2019). A history of shadow education in Japan and South Korea. English and EnglishAmerican Literature, 54, 1-42.

Sutton Trust. (2018). Private tuition still common for pupils. London: Sutton Trust. https://www.suttontrust. com/news-opinion/all-news-opinion/private-tuition-still-common-for-secondary-school-pupils, accessed 1 April 2020.

Think Mauritius. (2019). Rethinking the education system in Mauritius. Ebene: Think Mauritius.

Sutton Trust. (2019). One in four teachers take on private tuition outside of school. https://www. suttontrust.com/news-opinion/all-news-opinion/one-in-four-teachers-take-on-private-tuition-outsideof-school, accessed 1 April 2020.

Tang, V. T., Shaw, T. M., \& Holden, M. G. (Eds.). (2019). Development and sustainable growth of Mauritius. New York: Palgrave Macmillan.

UNESCO. (2000). The Dakar framework for action - education for all: Meeting our collective commitments. Paris: UNESCO.

UNESCO. (2015). World education forum 2015: Final report. Paris: UNESCO.

UNICEF. (1994). Situation analysis of women and children in Mauritius. New York: UNICEF.

UNICEF. (2019). Every child learns: UNICEF education strategy 2019-2030. New York: UNICEF.

United Nations. (1948). The universal declaration of human rights. New York: United Nations.

Walford, G. (Ed.). (2016). Privatisation, education and social justice. London: Routledge.

Ward, S. C. (2014). Neoliberalism and the global restructuring of knowledge and education. New York: Routledge.

Weale, S. (2018). 'An education arms race': Inside the ultra-competitive world of private tutoring. The Guardian, 5 December. https:/www.theguardian.com/education/2018/dec/05/an-education-arms-raceinside-the-ultra-competitive-world-of-private-tutoring.

World Bank, The. (1995). Priorities and strategies for education: A World Bank review. Washington DC: The World Bank. 
World Bank, The. (2006). From schooling access to learning outcomes: An unfinished agenda. Washington DC: The World Bank.

Yi, P. (2002). Household spending on private tutoring in South Korea. In Paper presented at the 46th annual conference of the Comparative \& International Education Society, Orlando, Florida.

Yung, K., \& Bray, M. (2017). Shadow education: Features, expansion and implications. In K. C. T. Tse, \& M. H. Lee (Eds.), Making sense of education in post-handover Hong Kong: Achievements and challenges (pp. 95-111). London: Routledge.

Zhang, W., \& Bray, M. (2017). Micro-neoliberalism in China: Public-private interactions at the confluence of mainstream and shadow education. Journal of Education Policy, 32(1), 63-81.

Zhang, W., \& Yamato, Y. (2018). Shadow education in East Asia: Entrenched but evolving private supplementary tutoring. In K. Kennedy, \& J. C. K. Lee (Eds.), Handbook on schools and schooling in Asia (pp. 323-332). London: Routledge.

Open Access. This is an open-access article distributed under the terms of the Creative Commons Attribution-NonCommercial 4.0 International License (https://creativecommons.org/licenses/by-nc/4.0/), which permits unrestricted use, distribution, and reproduction in any medium for non-commercial purposes, provided the original author and source are credited, a link to the CC License is provided, and changes - if any - are indicated. 